\title{
Undergraduates can publish too! A case study of a scientific team writing assignment leading to publication.
}

Chiara Gamberi ${ }^{\mathrm{a} *}$ and Katharine Hall ${ }^{\mathrm{b}}$

${ }^{a}$ Biology Department, Concordia University, Montreal, Canada $;{ }^{b}$ Concordia Library, Concordia University, Montreal, Canada

Chiara Gamberi (corresponding author)

Biology Department

Concordia University

7141 Sherbrooke St. W., SP-375-35

Montreal, Quebec

Canada H4B 1R6

514-343-6111, ext 43841

chiara.gamberi@concordia.ca

Katharine Hall

Vanier Library

Concordia University

7141 Sherbrooke St. W., VL-127-2

Montreal, Quebec

Canada H4B 1R6

514-848-2424, ext. 7772

katharine.hall@concordia.ca

This is an Accepted Manuscript of an article published in the

International Journal of Science Education on October 26, 2018, available online:

https://www.tandfonline.com/doi/full/10.1080/09500693.2018.1531439 


\section{Undergraduates can publish too! A case study of a scientific team writing assignment leading to publication.}

The design and implementation of a scientific writing assignment in a >100 student upperlevel undergraduate microbiology class resulted in a peer-reviewed publication in an openaccess journal. The primary course objectives and requirements were met by assigning groups of four to five students one of 25 distinct section topics of similar size and complexity that complemented the course materials. Students were taught to identify, read and cite primary scientific literature, to avoid plagiarism, and to share in productive interactions with peers throughout the assignment by a combination of class instructions, and personal and group mentoring. A team of volunteer students performed additional editing and compiling of the manuscript into the final cohesive, submitted review.

Keywords: science writing; undergraduate writing; science communication; collaborative learning; faculty-librarian collaboration

\section{Literature Review}

Articulating thoughts and communicating ideas clearly and effectively in written form is critically important to all scientific and professional careers (Jang \& Hand, 2017; Norris \& Phillips, 2003; Yore, Florence, Pearson \& Weaver, 2006; Yore, Hand \& Florence, 2004; Yore, Hand \& Prain, 2002). Scientific writing is, however, a complex skill, that is usually taught experientially and fostered through personal guidance and feedback. Co-authoring was found to be an effective way to teach scientific writing skills (Chaopricha, 1997; Florence \& Yore, 2004). Importantly, scientific writing is thought to promote the development of metacognitive capacity and skills necessary to formulate critical arguments which are central to scientific inquiry (Yore, Bisanz \& Hand, 2003) and can be used as a pedagogic tool in science education. Thus, an early 
introduction to the art of scientific writing is needed to effectively learn and develop wordsmanship (Alley, 1987; Osborne, 2010), to clearly convey one's ideas. Written communication skills need to be cultivated in high school through undergraduate and graduate studies, until practiced proficiently in professional settings.

Short article critiques and mini-reviews are common writing assignments in upper-level undergraduate courses in the sciences generally and biology in particular. Typically, however, such assignments do not resemble published articles neither in content nor format because they are prepared for the purpose of evaluation and for the teacher as only audience (Langer \& Applebee, 1987, as cited in Yore et al., 2003). Moreover, without timely and detailed feedback, they may not effectively teach students writing and argument-building skills needed for embarking in graduate studies and professional careers in science and technology.

Considering the pedagogical value of writing assignments, many efforts have been made to introduce scientific writing into the undergraduate curriculum (Colton \& Surasinghe, 2014; Glaser, 2014; Stanford \& Duwel, 2013; Walker \& Sampson, 2013). However, short semesters and large class size limit the opportunities to practice scientific discourse (Ford \& Forman, 2006). Critical evaluation of written assignments demands, however, substantial time on the part of the professor who, burdened by multiple commitments, may prefer to opt to assess students using the ever-popular multiple-choice questions. While practical to assess the acquisition of basic discipline-specific information, multiple choice questions are limited in their efficacy to introduce students to a discipline-specific culture and translatable science literacy. It has been shown that guiding students towards resolving "higher level questions" improved their academic performance (Wise \& Okey, 1983; Yore et al., 2003). Language can effectively promote 
conceptual understanding and knowledge-building through learning constructive discourse and using different language types to communicate with audiences other than the teacher (Driver, Newton \& Osborne, 2000; Ford \& Forman, 2006; Jang \& Hand, 2017; Norris \& Phillips, 2003; Yore et al., 2003; Yore et al., 2006).

Seeking to design a writing assignment that could model scientific inquiry and that could be readily implemented into different pre-existing course content to teach scientific communication skills in a "real-life" context, we chose to engage students in the experience of writing a review for submission to a peer-reviewed journal. The successful outcome of the first iteration of this large-scale writing experiment was achieved in a third-year microbiology class of more than 100 students through a method that has roots into the write-to-learn tradition (Jang \& Hand, 2017; Yore et al. 2003) and that to the best of our knowledge has not been reported in the previous literature.

\section{Rationale}

Writing-to-learn pedagogy was found to be an effective means to develop understanding of science as dynamically evolving and to help students' conceptual understanding (Jang \& Hand, 2017; Yore et al., 2003). Rather than reading and summarizing content, undertaking the more advanced task to elaborate on current scientific concepts mimics the reality of science inquiry, fostering science literacy and may be used to complement the textbook in two ways. First, the science presented in textbooks often appears as established and unchangeable (reviewed in Yore et al., 2003), devoid of the debate that is part and parcel with scientific practice. Second, most recent debates are often only partially covered in textbooks, yet they may become an excellent 
pedagogic subject with the interest of contemporary relevance. Moreover, student often underappreciate the iterative nature of science writing and the need of multiple rounds of reflection, writing and revision to refine one's ideas (Zimmerman \& Risemberg, 1997). When fostering the development of advanced skills, discussion and personalized feedback in small groups is optimal, which is, however, challenging to realize in the context of a class with over 100 students. Employing a concept of "strength in numbers", here a project was undertaken to examine a rapidly expanding topic within the course domain, with strategies to divide the large amount of information among the students, improve student understanding of the subject, foster the development of critical inquiry and to hopefully stimulate their interest for future explorations, while providing the opportunity of exposure to the demands of manuscript publication.

During the initial planning phases, two concerns arose that needed to be addressed in the project design: plagiarism and the laborious time commitment for the professor. A survey conducted by Hughes \& McCabe (2006) in 2002-2003 on academic dishonesty at 11 Canadian universities found that $53 \%$ of undergraduate students self-reported an incident of "serious cheating on written work" (p. 10). Thirty-seven percent admitted to copying from a source without referencing (Hughes \& McCabe, 2006, p. 10). A serious matter, plagiarism was a special concern to address in a written assignment aimed at publication because of its potential consequences on the reputation of all authors.

Concerns around the increased time commitment for such a project are not negligible. The evaluation of written assignments is inherently more time intensive for the professor than 
other assessment formats. Although the initiative to collectively write a review required initially a greater time investment, the project has generated an adaptable framework that will reduce efforts in subsequent assignments.

\begin{abstract}
Aims
To assess feasibility and efficacy of a writing-to-learn pedagogy in a third-year undergraduate course of more than 100 students, the aims included the development of an appropriate supportive structure (scaffold) for the assignment, the implementation of effective general and personalized guidance on a need basis, and the mitigation of plagiarism risks.
\end{abstract}

\title{
Methodology
}

\section{The Assignment}

The assignment was designed to teach behaviours conducive to good scientific writing by guiding students to experience the tasks and time commitment necessary to produce a publication-quality manuscript, as discussed in detail below. At the same time, the assignment was intentionally constructed to curb plagiarism. Considerations on assignment design, outlines, and information on advantages and disadvantages may be found in Table 1.

Similar to others (Moore, 1993; Patterson, 2001; Yore et al., 2003) we found that one cannot stress enough the importance of clear written instructions on the requirements of the assignment for student success and fundamentally minimizing time spent in grading. A copy of the assignment instructions provided to students may be found in Appendix 1. 
Table 1. Advantages and disadvantages to consider in assignment design and implementation.

\begin{tabular}{|c|c|c|}
\hline Consideration & Advantages & Disadvantages \\
\hline $\begin{array}{l}\text { Choose cutting- } \\
\text { edge topic }\end{array}$ & $\begin{array}{l}\text { Intellectually stimulating for its } \\
\text { many unresolved aspects. } \\
\text { Gives the students a chance to } \\
\text { become fascinated with the } \\
\text { advances and become part of the } \\
\text { progress. } \\
\text { Novelty and relatedness to our } \\
\text { lives motivates learning. } \\
\text { - If sufficiently novel, it may } \\
\text { complement textbook contents. }\end{array}$ & $\begin{array}{l}\text { Fast progress which may } \\
\text { outpace the students' } \\
\text { processing capacity or } \\
\text { experience. } \\
\text { - Possible lack of textbook } \\
\text { coverage and pre-existing } \\
\text { review papers may challenge } \\
\text { students inexperienced with } \\
\text { researching and writing. }\end{array}$ \\
\hline $\begin{array}{l}\text { Design a detailed } \\
\text { topical structure } \\
\text { of the review } \\
\text { prior to } \\
\text { assignment }\end{array}$ & $\begin{array}{l}\text { - Guides composition of the final } \\
\text { document. } \\
\text { - When properly planned, it may } \\
\text { support personal elaboration and } \\
\text { curb plagiarism. } \\
\text { - Reduces time spent by professor } \\
\text { responding to individual student } \\
\text { questions. }\end{array}$ & - May be perceived as rigid. \\
\hline $\begin{array}{l}\text { Provide } \\
\text { extensive list of } \\
\text { "seed" papers for } \\
\text { the assignment }\end{array}$ & $\begin{array}{l}\text { - Provides guidance to newer } \\
\text { students at their first writing } \\
\text { experience. } \\
\text { - Assigning one paper per student } \\
\text { ensures a minimum of papers of } \\
\text { appropriate scientific relevance are } \\
\text { studied and promotes fair work- } \\
\text { sharing. } \\
\text { - Students are still able to consult } \\
\text { additional sources and are } \\
\text { encouraged to do so. }\end{array}$ & $\begin{array}{l}\text { More time consuming for } \\
\text { the instructor. } \\
\text { May reduce student } \\
\text { motivation to engage in } \\
\text { further literature searching } \\
\text { and topic exploration. } \\
\text { However, this was not } \\
\text { observed in this case. }\end{array}$ \\
\hline $\begin{array}{l}\text { Assign working } \\
\text { groups }\end{array}$ & $\begin{array}{l}\text { Prevents possible situations of } \\
\text { student marginalization. } \\
\text { Encourages effective } \\
\text { communication with people } \\
\text { outside of a student's friend circle. } \\
\text { Interaction with new people may } \\
\text { discourage plagiarism. }\end{array}$ & $\begin{array}{l}\text { - Some students may resist the } \\
\text { idea of working with } \\
\text { somebody new to them. } \\
\text { - Students fear being affected } \\
\text { by possible "misdeeds" of } \\
\text { their peers. } \\
\text { For thorough discussion on } \\
\text { strategies for group composition } \\
\text { see Lawrie et al., 2014; Barkley, } \\
\text { Major \& Cross, 2014. }\end{array}$ \\
\hline
\end{tabular}




\begin{tabular}{|c|c|c|}
\hline $\begin{array}{l}\text { Provide } \\
\text { necessary } \\
\text { support system }\end{array}$ & $\begin{array}{l}\text { - Assign ample time to work through } \\
\text { the assignment (here we used one } \\
\text { month). } \\
\text { - Partner with librarian to provide } \\
\text { instruction and practice on how to } \\
\text { conduct literature searches and } \\
\text { how to properly paraphrase and } \\
\text { cite to prevent plagiarism. } \\
\text { - Note: Education that focuses on } \\
\text { defining plagiarism and } \\
\text { teaching proper paraphrasing } \\
\text { and citation techniques } \\
\text { empowers students to recognize } \\
\text { plagiarism and produce original } \\
\text { text more effectively than } \\
\text { focusing on its negative } \\
\text { consequences (Houtman \& } \\
\text { Walker 2010; Landau, Druen \& } \\
\text { Arcuri 2002; Fenster } 2016 ; \\
\text { Gonnarsson, Kulesza \& } \\
\text { Pettersson 2014; Willmott \& } \\
\text { Harrison 2003). }\end{array}$ & $\begin{array}{l}\text { - May require time investment } \\
\text { for guidance and responding } \\
\text { to individual queries. } \\
\text { - Note: Planning effective } \\
\text { guidelines and how to } \\
\text { manage group dynamics } \\
\text { in advance will reduce } \\
\text { efforts. } \\
\text { High commitment from the } \\
\text { instructor. A librarian and/or } \\
\text { a TA could support this } \\
\text { process effectively, } \\
\text { addressing the most common } \\
\text { concerns, demonstrating how } \\
\text { to analyze papers, search the } \\
\text { literature and leaving the } \\
\text { resolution of the most } \\
\text { complicated issues to the } \\
\text { professor. }\end{array}$ \\
\hline $\begin{array}{l}\text { Assign a clear } \\
\text { grading system }\end{array}$ & $\begin{array}{l}\text { Eases student anxiety. } \\
\text { Addresses all the concerns at the } \\
\text { start and responds to all the } \\
\text { specific issues that may arise } \\
\text { during the assignment. }\end{array}$ & $\begin{array}{l}\text { - Students may fear that the } \\
\text { instructor's personal bias } \\
\text { may affect paper grading. } \\
\text { After the first iteration, this } \\
\text { issue is predicted to resolve } \\
\text { itself. }\end{array}$ \\
\hline $\begin{array}{l}\text { Build responsible } \\
\text { behavior into the } \\
\text { assignment }\end{array}$ & $\begin{array}{l}\text { - Sets tone for group interactions } \\
\text { and encourages group } \\
\text { accountability. } \\
\text { - Assignment structure (see } \\
\text { Appendix 1): } \\
\text { - Limit document size to mimic } \\
\text { current publishing formats, } \\
\text { while promoting succinct } \\
\text { writing. } \\
\text { Require paper outline to } \\
\text { encourage careful planning of } \\
\text { the document contents. }\end{array}$ & - None. \\
\hline
\end{tabular}




\begin{tabular}{|c|c|c|}
\hline & $\begin{array}{l}\text { Require author's contribution } \\
\text { statement to promote equal } \\
\text { work distribution and the } \\
\text { conscious realization of all the } \\
\text { tasks necessary to prepare } \\
\text { publication-quality documents. }\end{array}$ & \\
\hline $\begin{array}{l}\text { Involve student- } \\
\text { editors in the } \\
\text { assembly and } \\
\text { editing of the } \\
\text { final manuscript }\end{array}$ & $\begin{array}{l}\text { - Student-editors will gain } \\
\text { additional, potentially } \\
\text { transferrable, professional skills. } \\
\text { - High pedagogical value. } \\
\text { - Note: one student-editor was } \\
\text { hired by a company } \\
\text { immediately after graduation, in } \\
\text { part because of the unique } \\
\text { achievement of accomplishing } \\
\text { this project. }\end{array}$ & $\begin{array}{l}\text { Because of novice student- } \\
\text { editors, this phase may } \\
\text { require longer time to } \\
\text { completion than with } \\
\text { experienced writer. }\end{array}$ \\
\hline
\end{tabular}

\section{Review paper topic}

The review topic was selected to impact on a "cutting-edge", fast-paced and rapidly expanding field in part to explore an area of research that was insufficiently and superficially covered in course textbooks. A key goal was to offer the students opportunity to discover the excitement of researching, interpreting and elaborating on recent information from primary research. More discussion on the topic selected for this review paper may be found in Appendix 2.

\section{Collaborative learning framework}

Inherent in the assignment design was collaboration, because multiple authored publications are commonplace in scientific disciplines. Exposure to collaborative learning environments early in their academic experience through a group writing assignment was intended to prepare students for scientific careers in which team work has become an essential skill. For many students, the assignment was their first scientific writing experience, and the collaborative project provided helpful peer-support and mitigated isolation and negative emotions that are known to arise when 
writing (Ross, Burgin, Aitchison \& Catterall, 2011). Through learning together and coaching one another, student collaboration provided guidance, accountability, and goal-setting within the group.

Group membership was randomly determined by the professor. Twenty-seven groups were composed of four to five students. Guidelines were provided for managing internal group dynamics to enhance productive peer interaction. Students were also taught modalities for constructive interaction in a case by case fashion and were encouraged towards working on their texts with multiple rounds of reflection, writing and corrections. To discourage procrastination, students were asked to nominate a time-keeper, who monitored progress and set goals to meet the assignment deadline.

\section{Group assignment: Scaffolding and implementation}

An outline (see Appendix 2) listing the main sections of the review was given ahead of time to establish the scope of the project. The structured outline eased student anxieties in undertaking a “non-traditional” assignment and facilitated assembly of the final review.

Each of the 27 groups was provided with one of 25 subtopics (Appendix 2) and a starter set of four to five "seed" publications. The professor selected and assigned all "seed" papers to each group, which in a large class can be laborious, however this undertaking ensured the pedagogic value of the assignment. The assignment of one article per student was not intimidating, due to its similarity to tasks in other courses. Ensuring consultation of a minimum of appropriate source content per student, the "seed" articles guaranteed pedagogic value and compensated for limited bibliographic search experience. Curiosity-driven research was 
stimulated by guiding students to address specific questions through expanded bibliographic searches. Although each student was assigned one "seed" publication, each was encouraged to consult as many other articles as needed as they discovered open questions, and to use the set of "seed" publications to judge the relevance and quality of related literature. One review article was included among the "seed" publications to provide each group with a model of the desired outcome of the assignment, as well as background information to help clarify the nature of their topic.

In addition to their completed assignments, groups were required to submit an outline of the logic and structure of their arguments. The outline was intended to encourage thoughtful planning of their assignment paper. The students' final papers were restricted to three pages, single-spaced and were to be written with specific guidelines (see Appendix 1). The assignment paper, along with the outline, was graded for ability to demonstrate content prioritization, logic, and overall focus on the final document structure.

\section{Librarian involvement}

The biology librarian was instrumental in offering formal instruction to the students on bibliographic searching, proper citation and avoiding plagiarism. In one course lecture, the librarian covered bibliographic searches and proper citation. Plagiarism was clearly explained, along with instruction on correct methods to quote, paraphrase and summarize published literature. Emphasis was placed on proper paraphrasing with examples and working exercises through which students were guided to apply their understanding of idea theft. Outside of class time, the librarian provided follow-up support on database searching, interlibrary loans, reference 
management and plagiarism to individual students and groups as they proceeded to gather information.

\section{Measures to deter plagiarism}

To reinforce the importance of producing original content, students were required to sign a declaration that their text was checked for plagiarism disclosing their method. Because students who knew their text would be scanned for plagiarism were shown to work more diligently to avoid it (Gray-Mitsumune, 2014), the assignment instructions stated that each paper was going to be checked. Any instance of plagiarism would void all marks and incur in penalties as per the University's Academic Code of Conduct. Here we relied on a combination of Google searches and two free plagiarism checkers (PlagTracker and $\underline{\text { Plagium }})$ to screen all submissions. Institutional plagiarism scanners, if available, could facilitate this analysis.

\section{Grading}

All group members received the same final grade. Students initially had concerns about fair grading which were dispelled by clarifying that most scientific papers are, indeed, written in teams and by providing a clear grading scheme highlighting the factors contributing to the grade (e.g., logic construction of the argument, scientific content and accuracy) versus those provided for the sole benefit of the student (e.g., comments on writing style or outline effectiveness, suggestions for alternative phrasing and argument presentation, spelling). Modelled on those requested by many journals, a signed statement describing the contributions of each author was demanded of each group to encourage fair work-sharing and reinforce recognition of all the requirements to produce the manuscript. 
Although different grading strategies have their advantages and disadvantages, here shared group marking modelled credit for scientific publications; it has also been acknowledged to promote cohesion, and may decrease incidents of plagiarism, because team members must rely on each other to achieve success (Winchester-Seeto, 2002).

\section{Managing group dynamics}

Team work did, occasionally lead to dispute, but such occurrences become important teaching moments to discuss and implement conflict resolution strategies. A plan for managing group dynamics is recommended to minimize professor intervention. While in this case students demonstrated effective abilities to resolve most disputes without intercession from the professor, two of the 27 groups did have irreconcilable issues that required separation of the members.

\section{Manuscript assembly and editing}

Assembly of the group contributions and editing was undertaken after course completion. Two motivated students with aspirations in publishing and graduate careers volunteered for this editorial experience to revise the manuscript until accepted for publication. Eight, 60-90 minute meetings were held with them over the course of one year to assess progress and give individual guidance. To recognize their greater contributions, these students became the lead authors on the published review.

To honour student privacy, all original papers were stripped of author names and deposited under file topic descriptions in a common Dropbox folder that was shared among the editorial team. Tasked to assemble the separate sections into a final document, the studenteditors were given instruction in editing original contributions, checking source references for 
accuracy and selecting relevant contents for a cohesive final document. Moreover, they updated content with new literature published in the interim. Regular meetings with the professor were held during the assembly of the final manuscript to discuss specific challenges encountered during project curation and to offer guidance and mentorship.

Once the first round of editing was completed, the professor revised the text, proofed content and polished the document. Although the first draft revealed a comprehensive review covering themes from original publications and appropriate additional sources, signs of inexperienced scientific writing were present. This included frequent citation of reviews instead of primary sources, overly assertive tones in commentary unwarranted by experimental evidence, and minimization of important ongoing debates. The novice undergraduate student-editors were somewhat astonished by the high standards for contemporary scientific publication yet gained appreciation for the subtleties of language in scientific parlance, and the need for clear elaboration. In this teaching opportunity, editing was performed to meet publication standards, while preserving manuscript character, and trust was placed in the peer-review process to help point out the need for further revision.

\section{Choice of publication venue, submission and peer review}

Investigating publication venues for the final review, open access journals were prioritized, because the large number of contributors and their imminent graduation required dissemination in an accessible and sharable medium. Open Access publication also allowed for the review be accessible beyond its targeted microbiology audience, in line with its pedagogical scope. Project funding for author publishing charges presented, however, a barrier for Open Access publication; 
institutional support through our Library's Open Access Author Fund helped offset the cost, part of which was further defrayed by the publisher.

After rejection by a journal uninterested in a didactic project, the manuscript was submitted to Frontiers in Microbiology, which sent it out for review. Embodying their educational role, the reviewers and editor appreciated the project and gave specific comments that guided the student editors to make extensive revisions, to remove the assertive tone, to add primary source referencing, and to enhance presentation (e.g., adding a figure). Performing revisions, the student-editors experienced first-hand all the emotional phases that authors encounter during peer-review from initial denial and rejection of criticism to acceptance of the merits of the feedback and action to improve content for publication. Guided through the process, the students addressed each point in their rebuttal letter, which was ultimately composed by the professor. The revised manuscript was accepted for publication without further changes.

\section{Technical considerations for large group-authored manuscripts}

Among important considerations before submission, the text needed to be approved by all authors, and not inadvertently shared on social media before publication. By uploading the final draft to the university institutional repository as a read-only document, a record of prepublication and authorship was established with a medium for author review and feedback. Risks of further dissemination were also reduced as compared to using a subject-specific pre-print server such as BioR $\chi$ iv. The institution also withdrew the manuscript from public view during peer-review. 


\section{Results}

\section{Quality of the student-composed texts}

All groups but one respected the assigned format. The requirement of equal lengths of text modelled journal format, promoted synthesis and content prioritization and facilitated equitable evaluation. The maturity of the arguments was variable, as expected for a third-year course with students from second to fourth year of study curriculum. Many papers were characterized by a tone of certainty that resembled that of a textbook more than that of a scientific publication. This was previously noted in other contexts (Norris \& Phillips, 2003; Yore et al., 2003) and may suggest the need to adopt write-to-learn strategies more generally to improve science literacy and the appreciation of science as an inquisitive discipline. Moreover, students had the tendency to focus more on the methods and process than on the significance of the studies presented and their conceptual relationship with the other consulted papers, albeit more mature papers were produced in teams with high cohesion. Consistent with the novice status of the writers, the tendency was for in-text citations of only one or two papers at once and weak correlation among the published literature. Similar to Yore et al. (2003), we also found that students in general did not initially appreciate that multiple rounds of revision are necessary to elaborate ideas; such concept was, instead, better understood by the end of the assignment.

\section{Plagiarism}

We detected only one instance of bad paraphrasing, suggesting that the combination of education, a signed declaration, and the certainty of a scan of submitted texts, effectively averted incidence of plagiarism. 


\section{Publication}

Selber-Hnatiw et al. (2017). Human Gut Microbiota: Toward an Ecology of Disease. Frontiers in Microbiology: https://doi.org/10.3389/fmicb.2017.01265

The assignment was validated globally as an effective pedagogic tool by the positive evaluation of the students, who gained valuable real-life experience, and by the scientific community, which took over 7,500 views of the review within the first five months after publication and over 12,000 within the first year.

\section{Reflections and conclusion}

\section{Consensus and structuring}

The establishment of effective guidelines to structure the assignment (a form of "scaffolding" as previously defined (Davis 2000; Reiser et al., 2001; Yore et al., 2003) was critical to ensure proper navigation through the project and deserves appropriate preparation time to minimize interventions during the process due to student uncertainty. Consultation with many colleagues about the assignment design produced both negative and positive feedback that was instrumental in planning how to circumvent pitfalls, discourage unwanted behaviour and promote productive writing skills.

\section{Discouraging plagiarism and increasing pedagogic value}

Random group assignment, detailed guidelines and assignment expectations, a mandatory outline, signed declaration of originality, informing students that all papers would be screened for plagiarism and a lecture on proper citation and paraphrasing were all elements intentionally 
included into the assignment to discourage and hinder plagiarism. Many occurrences of plagiarism are due to an incomplete understanding of the issue, thus we chose to focus on teaching proper citation etiquette with relevant examples and activities, which is reported to be more effective than focusing solely on negative consequences of plagiarism (Fenster, 2016; Gonnarsson, Kulesza \& Pettersson, 2014; Houtman \& Walker, 2010; Landau, Druen \& Arcuri, 2002; Willmott \& Harrison, 2003). Although plagiarism was by far the largest concern, responsible academic behaviour was effectively taught and peril of its affecting the final publication was further minimized during the editing process.

\section{Time commitments}

While the time commitment and effort required for introducing a new style of assignment is greater than sticking to the status quo, the pedagogic value of this type of assignment was also much greater. In hindsight, there were areas where the time investment of the professor could be better optimized. For example, "seed" publications were read completely in advance, but could have been only carefully scanned for appropriateness; a graduate teaching assistant, if available, could assist during post-course editing, while improving their own editorial skills.

The "normalization" of such student assignments as pedagogic tools employed in subsequent classes (especially if also adopted by other colleagues) to establish a "local culture" in which scientific writing is more commonplace in the curriculum is expected to significantly decrease the time demands for participating professors. The student's positive reviews after the course indicated that similar assignments may encounter less resistance, especially in light of the success of this first initiative. 
In this case, the merging of student papers into one cohesive review, submission and response to peer reviewer comments occurred with student-editors, conferring greater educational benefit to those few student editors engaged after course completion. However, one could envision an environment where this style of course assignment was introduced during the first and second year to build capacity amongst student; once students reach the third and fourth year, elements of peer-review and editing each other's papers could be taught as part of the course work, further enhancing the pedagogical value.

\section{Pedagogic value and student response}

Although peer-reviewed publication does affirm the value of this assignment independent of the course settings and provided a sense of pride to all student co-authors, the process had inherent value, regardless of publication outcome. Students engaged in writing-to-learn programs developed a deeper understanding of the scientific concepts (Driver et al., 2000, Gunel, Hand \& McDermott, 2009; Jang \& Hand, 2017) and appreciate that science is a discipline and constantly evolving (Yore et al., 2003). Introducing learning paradigms that "mimic scientific inquiry" has been recommended as an effective didactic approach (Jang \& Hand, 2017). Teaching scientific argumentation was found to induce long-lasting improvements in multiple disciplines (Shayer \& Adey, 1993). Interviews conducted by Ross et al. (2011) indicated that doctoral science students were ill-prepared for writing and receiving critique; receiving feedback was perceived, unexpectedly, as a time of high emotional stress and anxiety, rather than a means to achieve their higher potential. Thus, early demonstration of the process to take criticism during the undergraduate experience is expected to better prepare students for graduate studies and other 
professional careers. Moreover, writing helps experienced scientists to identify novel lines of investigation (Florence \& Yore, 2004) and was found to generate novel ideas and improved understanding of the subject in students at various level of education (Yore et al., 2003). In this case over $90 \%$ of the students recognized the value of the experience. They recommended, both personally and through the comment section of their teaching evaluations, to keep the assignment as part of the course in the upcoming years. Their final attitude pointed to the value of the experience, even more so after publication, which echoes the pride and satisfaction in seeing one's writing published as reported previously (Ross et al., 2011).

Preparing students to become critical readers and effective communicators is particularly important in the internet age when scientific literacy has become key to discern between justified and false claims. Thus, the benefits of this type of assignment appear to far outweigh the costs and encourage the design of efficient scaffolding to support effective student learning even with current time demands pressing on the professor.

\section{Future assignments}

Despite successful publication of the review, the perception among most colleagues is that the accomplishment was a unique experience that will not be repeated. Scientific writing remains, however, a complex skill that requires practice and thorough feedback. Through the investment of more time than a traditional assignment, new opportunity was unveiled for undergraduate students to improve their academic scientific writing abilities. Moreover, the assignment is a foundation meriting further development, because of its ability to empower pride and motivation in students as they witness the publication of their final product. Undaunted, the review 
assignment is currently being tailored to other upper level undergraduate courses.

\section{Acknowledgements}

We would like to thank Dr. Patrick Gulick, Dubravka Kapa and Dr. William D. Lubell for feedback on earlier drafts of this manuscript. Additional thanks to Dr. William D. Lubell, Dr. Patrick Gulick and Dr. Madoka Gray-Mitsumune for the initial discussion and opinions on assignment design. CG is the recipient of a Professional Development Award from CUPFA. 


\section{References}

Alley, M. 1987. The craft of scientific writing. Englewood Cliffs, NJ: Prentice-Hall.

Barkley, E. F., Major, C. H., \& Cross, K. P. (2014). Collaborative learning techniques: A handbook for college faculty (2nd ed.). San Francisco: Jossey-Bass \& Pfeiffer.

Chaopricha, S. (1997). Coauthoring as learning and enculturation: A study of writing in biochemistry (Doctoral dissertation). Available from ProQuest Dissertations and Theses database. (UMI No. 9736072).

Colton, J. S., \& Surasinghe, T. D. (2014). Using collaboration between English and biology to teach scientific writing and communication. Journal of College Science Teaching, 44(2), 3139.

Davis, E. A. (2000). Scaffolding students' knowledge integration: Prompts for reflection in KIE. International Journal of Science Education, 22(8), 819-837.

Driver, R., Newton, P., \& Osborne, J. (2000). Establishing the norms of scientific argumentation in classrooms. Science Education, 84(3), 287-312.

Fenster, J. (2016). Teaching Note—Evaluation of an avoiding plagiarism workshop for social work students. Journal of Social Work Education, 52(2), 242-248.

Florence, M. K., \& Yore, L. D. (2004). Learning to write like a scientist: Coauthoring as an enculturation task. Journal of Research in Science Teaching, 41(6), 637-668.

Ford, M. J., \& Foreman, E. A. (2006). Redefining disciplinary learning in classroom contexts. Review of Research in Education, 30(1), 1-32.Glaser, R. E. (2014). Design and assessment of an assignment-based curriculum to teach scientific writing and scientific peer review. Journal of Learning Design, 7(2), 85-104. 
Gray-Mitsumune, M. (2014, July). How to discourage academic dishonesty. Poster session presented at Plant Biology: American Society of Plant Biologists Annual Meeting, Portland, OR.

Gunel, M., Hand, B., \& McDermott, M. A. (2009). Writing for different audiences: Effect on high-school students' conceptual understanding of biology. Learning and Instruction, 19(4), 354-367.

Gunnarsson, J., Kulesza, W. J., \& Pettersson, A. (2014). Teaching international students how to avoid plagiarism: Librarians and faculty in collaboration. The Journal of Academic Librarianship, 40(3), 413-417.

Houtman, A. M., \& Walker, S. (2010). Decreasing plagiarism: What works and what doesn't. Journal on Excellence in College Teaching, 21(1), 51-71.

Hughes, J. M. C., \& McCabe, D. L. (2006). Academic misconduct within higher education in Canada. The Canadian Journal of Higher Education, 36(2), 1-21.

Jang, J-Y., \& Hand, B. (2017). Examining the value of a scaffolded critique framework to promote argumentative and explanatory writings within an argument-based inquiry approach. Research in Science Education, 47(6), 1213-1231.

Landau, J. D., Druen, P. B., \& Arcuri, J. A. (2002). Methods for helping students avoid plagiarism. Teaching of Psychology, 29(2), 112-115.

Lawrie, G. A., Gahan, L. R., Matthews, K. E., Weaver, G. C., Bailey, C., Adams, P., . . Taylor, M. (2014). Technology supported facilitation and assessment of small group collaborative inquiry learning in large first-year classes. Journal of Learning Design, 7(2), 120-135. 
Moore, R. (1993). Does writing about science improve learning about science. Journal of College Science Teaching, 22(4), 212-217.

Norris, S. P., \& Phillips, L. M. (2003). How literacy in its fundamental sense is central to scientific literacy. Science Education, 87(2), 224-240.

Osborne, J. (2010). Arguing to learn in science: The role of collaborative, critical discourse. Science, 328(5977), 463-466.

Patterson, E. M. (2001). Structuring the composition process in scientific writing. International Journal of Science Education, 23(1), 1-16.

Reiser, B., Tabak, I., Sandoval, W. A., Smith, B. K., Steinmuller, F., \& Leone, A. J. (2001). BGuILE: Strategic and conceptual scaffolds for scientific inquiry in biology classrooms. In S. M. Carver \& D. Klahr (Eds.), Cognition and instruction: Twenty-five years of progress (pp. 263-305). Mahwah, NJ, US: Lawrence Erlbaum Associates Publishers.

Ross, P. M., Burgin, S., Aitchison, C., \& Catterall, J. (2011). Research writing in the sciences: Liminal territory and high emotion. Journal of Learning Design, 4(3), 14-27.

Shayer, M. \& Adey, P. (1993). Accelerating the development of formal thinking in middle and high school students IV: Three years after a two-year intervention. Journal of Research in Science Teaching, 30(4), 351-366.

Stanford, J. S., \& Duwel, L. E. (2013). Engaging biology undergraduates in the scientific process through writing a theoretical research proposal. Bioscene: Journal of College Biology Teaching, 39(2), 17-24. 
Walker, J. P., \& Sampson, V. (2013). Argument-driven inquiry: Using the laboratory to improve undergraduates' science writing skills through meaningful science writing, peer-review, and revision. Journal of Chemical Education, 90(10), 1269-1274.

Willmott, C. J., \& Harrison, T. M. (2003). An exercise to teach bioscience students about plagiarism. Journal of Biological Education, 37(3), 139-140.

Winchester-Seeto, T. (2002, April). Assessment of collaborative work-collaboration versus assessment. Invited paper presented at the Annual Uniserve Science Symposium, Sydney Australia.

Wise, K. C., \& Okey, J. R. (1983). A meta-analysis of the effects of various science teaching strategies on achievement. Journal of Research in Science Teaching, 20(5), 419-435.

Yore, L. D., Bisanz, G. L., \& Hand, B. M. (2003). Examining the literacy component of science literacy: 25 years of language arts and science research. International Journal of Science Education, 25(6), 689-725.

Yore, L. D., Florence, M. K., Pearson, T. W., \& Weaver, A. J. (2006). Written Discourse in Scientific Communities: A conversation with two scientists about their views of science, use of language, role of writing in doing science, and compatibility between their epistemic views and language. International Journal of Science Education, 28(2-3), 109-141.

Yore, L. D., Hand, B. M., \& Florence, M. K. (2004). Scientists' views of science, models of writing, and science writing practices. Journal of Research in Science Teaching, 41(4), 338369.

Yore, L. D., Hand, B. M., \& Prain, V. (2002). Scientists as writers. Science Education, 86(5), 672-692. 
Zimmerman, B. J., \& Risemberg, R. (1997). Becoming a self-regulated writer: A social cognitive perspective. Contemporary Educational Psychology, 22(1), 73-101. 


\section{Appendix 1: Biology 371 Assignment}

In addition to the written instructions, the assignment was introduced in class and further

explanation, outline and "seed" papers were provided. For more information on the topic and

outline for this specific assignment, see Appendix 2.

\section{BIOL371 Assignment}

Each group will work together to produce a document.

\section{Checklist:}

1- Immediately verify the group you belong to in the posted file

2- Immediately verify the assigned paper list

a. Go to PubMed: http://www.ncbi.nlm.nih.gov/pubmed/ and find the assigned papers

b. Verify that your papers are either Open Access or posted in the BIOL371 reserve list.

If that is not the case, please communicate with the professor asap.

3 - Read the assigned papers on your own first (and the other readings assigned in class if you have not done it yet)

4- Draw a list of important items from the papers (advancements, novelty, confirmation of previous findings, shortcomings) and sketch out a theme for the chapter

5- Communicate with your other team members to:

a. Discuss the papers

b. Organize how to work on your section

c. Draw a timeline with intermediate goals

d. Nominate a "time keeper" that will monitor the progress of the project for the group and promote development and timeliness

e. Write your section

Suggestions for a strong manuscript:

1. Develop an outline of the section with the logical structure of your document and the points you want to make

2. Write the corresponding text

3. Edit extensively to eliminate redundancies and inaccuracies

f. Produce the statement of author's contribution (maximum ONE page). Each group member will declare their contributions to the assigned section and -if applicablewhether they contributed in ways different than the other group members. In this case grading may be adjusted. Please note that the group will produce only ONE statement that must be approved from all group members.

6- During the preparation of your assignment, feel free to consult other publications as needed, both for the sake of the final publication and for your own interest. If you decide to 
incorporate in your section information from additional publications you must reference your sources appropriately.

7- Before submission, please check your document for plagiarism using both Google and Google Scholar and BRIEFLY describe your testing criteria.

\section{Document format:}

Text: maximum 3 pages, 1-inch margin, single spaced, Font and size: Times 12

References: no limit.

Use RefWorks to manage your references (available through the Concordia Library, contact the Biology Librarian Katharine Hall if you need assistance).

\section{Submission:}

Each group will submit the following:

1- One Word file complete with references via Moodle by the deadline November 20

2- One printout of the following, in class on November 21:

a. The complete text file

b. Signed author declaration

c. Section outline

Deadline is November 20 (firm). Late penalties: 10\% off grade for the first late day, $25 \%$ for the second day, $40 \%$ for the third day etc. In case of extreme individual circumstances, the student(s) should contact the professor so that alternatives can be arranged.

\section{Grading:}

Scientific content $40 \%$, logical structure $30 \%$, conceptual flow and appropriate terminology $30 \%$. Although in my feedback I may give suggestions related to English usage for your own development as scientists, this aspect will not be graded. Penalties for missing submitted material: 10\% each a, b, c in Submission section above. Evidence of plagiarism at any stage will void any marking assigned previously and may incur in disciplinary actions as per Concordia rules on the matter.

For any additional questions that may arise during the course of this assignment, please consult the professor at [email]

Enjoy!! 


\section{Appendix 2. Designing the assignment and review paper outline.}

The instructor searched the published literature to delineate all the review topics and sub-topics shown below. The theme of the interaction between the human host and the gut microbiota was chosen because it is new and varied, there is a recent plethora of discoveries and it has relevance to people because of its broad effects on health, diet, child birth etc. Moreover, because of its novelty, the subject was only superficially covered in the textbook, which increased the pedagogic value, simultaneously making the resulting document interesting from the academic publishing standpoint. Most published research analysed the relationship between host and gut microbiota from the perspective of the human subject and the consequences for its health. To maintain a relevance to the course subject of microbiology, the students were, instead, invited to consider the processes from the viewpoint of the microbial component with its peculiar ecology. Such "reversed" perspective was further strengthened during the final editing. The published document reflects extensive elaboration during which contents were selected and integrated from the initial documents, the student-editor's and professor's contributions (e.g., quality, relevance, accuracy), and the reviewers' requests. For example, sections $6 \mathrm{~d}-\mathrm{f}$ below were deleted or severely reduced to maintain the review focus. In such case, the students who contributed text to these sections remained co-authors to maintain the spirit of the initiative, and their contribution explained in the section of author's contributions as “... -authors- contributed text on.... that allowed the development of the review in its current state, albeit it is not represented in the current manuscript”.

The professor's primary research interest in the chosen review topic may certainly be an asset for a project like this. However, every experienced scholar can evaluate and integrate 
published information on a topic of interest. An outsider may also provide with a fresh view of the field, which in this case has been particularly appreciated, both through direct expert feedback to the professor and through the review becoming the top 5\% by most viewed article in the quarter it was published and garnering over 7500 article views and over 1260 downloads within five months of its publication.

\section{OUTLINE}

What is a healthy microbiota?

\section{Microbe-microbe interactions}

a- Factors affecting gut colonization (nutrients, polysaccharides, PULs)

b- Competition and colonization

c- Dietary iron and Salmonella

\section{Mechanisms of host modulation of gut microbial communities}

a- Adhesion mechanisms and adhesins

b- Oxidative stress, reactive oxygen species, reactive nitrogen species

c- Antimicrobial peptides

d- Interactions host immune system- gut microbiota

\section{Microbe-microbe interactions and microbial adaptations}

a- Metabolite exchange and virulence

b- Harmful bacteria

c- Interactions with the host immune system. Unlike $2 \mathrm{~d}$, this topic examined the microbial adaptations to the activity of the host's immunity.

\section{Physiological functions of the gut microbiota}

a- Chronic pathologies with altered microbiome profile

b- Acute pathologies with altered microbiome profile

c- Effects of enteric pathogens (short- and long-term)

d- Chemical Symbioses 


\section{Diet effects on the microbiome}

a- Does diet matter?

b- Metabolic effects of aspartame in obese model rats

c- Traditional fermented foods, supplementation and persistence of probiotic strains

d- Dietary modulations and auto-inflammatory disease

e- Diet-induced microbiota alterations (cultural/geographical differences, starvation, seasonal cycles)

\section{Changes in gut microbiota composition}

a- Developmental growth

b- Diet (also see 5a, c, e)

c- Supplementation with probiotic strains, efficacy, persistence of the probiotics

d- Antibiotic treatment and effects on the commensal microorganisms (horizontal gene transfer and resistome)

e- Genetic engineering to restore healthy intestinal microbiota

f- Fecal transplants: efficacy, legal implications 